\title{
First report of banana bunchy top disease on banana in Bengkulu
}

\author{
Mimi Sutrawati, and Sempurna Ginting \\ Departement of Plant Protection, Universitas Bengkulu \\ Corresponding Author: mimi_sutrawati@unib.ac.id
}

\begin{abstract}
Banana is a horticulture crop that has economic value and is widely cultivated in tropical countries. Banana production in Bengkulu province reached 259,748 quintals, then durian (110,387 quintals), tangerines (94,396 quintals) (BPS 2015). Banana bunchy top disease caused by Banana bunchy top virus (BBTV) infection is considered the most crucial virus disease affecting yield losses of a banana plantation in Asia, Africa, and the South Pacific. However, the incidence and molecular characters of BBTV has never been reported in Bengkulu. This research aims to characterize symptom variations, disease incidence, and disease severity of BBTV infection in Bengkulu and virus detection using molecular methods by polymerase chain reaction (PCR). Disease incidence of BBTV was measured based on field symptoms. The disease survey was conducted in Bengkulu city, Bengkulu Utara district, and Rejang Lebong district. The study showed that the incidence of BBTV in Bengkulu City, Bengkulu Utara, and Rejang Lebong ranged from $0 \%$ to $100 \%$. The most common symptoms observed in the field involved vein clearing, upturned leaf, chlorotic, and ragged margins, reducing petiole length, distance, lamina width, and stunting. Banana crops that are infected with BBTV in the vegetative phase will not produce fruit. In contrast, viral infection in the generative phase causes the formation of stunted fruit that is not suitable for harvesting. Thus, the potential loss of yield due to stunted disease can reach $100 \%$. This study's results are the first reports of BBTV infection in banana crops in Bengkulu. Disease diagnosis will form the basis of disease control strategies in banana crops.
\end{abstract}

Keywords : Bunchy top disease, disease incidence, disease severity, symptom

Reference to this paper should be made as follows :

Sutrawati, M and S. Ginting. 2020. First Report of Banana Bunchy Top Disease on Banana in Bengkulu. Agritropica: Journal of Agricultural Science. 3(2): 82-87. Doi:

https://doi.org/10.31186/Jagritropica.3.2.82-87

\section{INTRODUCTION}

Banana is a horticulture crops that has economic value and is widely cultivated in tropical countries. Banana is one of important fruits in Bengkulu. Banana production in Bengkulu province reached 259,748 quintals, then durian (110,387 quintals), tangerines (94,396 quintals) (BPS 2015). Banana bunchy top disease (BBTD) is considered as the most important virus disease affecting banana plantation in Asia, Africa, and South Pacific (Furuya et al., 2005; Hooks et al., 2009). Banana bunchy top disease (BBTD) is caused by the
Banana bunchy top virus (BBTV), which is a species of the genus Babuvirus in the family Nanoviridae.

BBTD is dispersed over long distances through the exchange of infected suckers and / or through nonvirus indexed tissue culture (TC)derived plantlets (Thomas \& Caruana, 2000). Through these propagules, the virus is introduced into new areas where the banana aphid Pentalonia nigronervosa (Hemiptera, Aphididae) occurs (Almeida et al., 2009). This virus only transmitted persistently by its specific vector, banana aphid, Pentalonia nigronervosa (Hemiptera: Aphididae). 
BBTV is a member of Genus Babuvirus in Family Nanoviridae, containing at least six genome components, each approximately $1000 \mathrm{bp}$ size. The six genome components referred to DNA-R, DNA-U3, DNA-S, DNA-M, DNA-C, and DNA-N,encoding different types of protein (King et al. 2012). BBTV isolates in the world fall into two geographic phylogenetic groups, the South Pacific group (SPG) and Asian group (AG) based on genome components (Karan et al. 1994).

In the 1990s, the first severe outbreak of BBTD in Africa was estimated to have reduced banana production in the Nkhatabay and Nkhotakota districts of Malawi from 3500 ha to about 800 ha (Soko et al., 2009; Kumar et al., 2011). Although accurate estimates of yield losses are lacking for the Great Lakes countries of Africa, about $90 \%$ yield loss was reported in severely BBTD-infected plants of susceptible cultivars such as Poyo and AAA-Cavendish in a screening trial conducted in the Rusizi valley, in Burundi (Niyongere et al., 2011a). Because of the high destructive potential of the disease, Banana bunchy top virus (BBTV) was listed as one of the world's 100 worst invasive species and the International Plant Protection
Convention included it as a pathogen to be subjected to rigorous quarantine measures (IPPC, 2010; Kumar et al., 2011). The incidence of BBTD in Indonesia has been reported in Sumatra, Bali, and Special Territory of Yogyakarta (Furuya et al. 2004; Pinili et al. 2011; Chiaki et al. 2015). However, the incidence and molecular characters of BBTV has never been reported in Bengkulu. The objective of this research was to characterize symptom variations, disease incidence, and disease severity of BBTV infection in Bengkulu, Indonesia.

\section{MATERIALS AND METHODS}

\section{Field Survey}

Survey was conducted on several banana plantations in Bengkulu city, Rejang Lebong district, and Bengkulu Utara district, Bengkulu province. Infection of BBTV was observed using purposive sampling method based on BBTV common symptoms i.e. stunting, bunched up leaves, and streaking between leave margins and midrib. Disease incidence (DI) of BBTV in each plantation was calculated using the following formula:

$$
\mathrm{DI}=\frac{\sum \text { sigmptomatic plants }}{\sum \text { total banana population }} \times 100 \%
$$

Table 1 Description of BBTV symptom severity

\begin{tabular}{ll}
\hline Symptom Severity & \multicolumn{1}{c}{ Symptom Description } \\
\hline Mild infection & $\begin{array}{l}\text { Limited vein clearing and dark green streaks on the lower } \\
\text { part of lamina and on petiole. No significant reduction of } \\
\text { lamina width. }\end{array}$ \\
& $\begin{array}{l}\text { Vein clearing, upturned leaf, chlorotic, and ragged margins. } \\
\text { Intermediate }\end{array}$ \\
& Significant reduction in petiole length, distance, and lamina \\
& width. \\
Brittle lamina with upturned, chlorotic, and ragged margins, & sometimes with necrotic symptom. Leaves failed to \\
emerged, giving a clear bunched appearance.
\end{tabular}


Based on the severity of the symptoms, the level of infection was categorized into three groups, i.e. mild, intermediate, and severe infection (Table $1)$.

\section{Virus Detection by Polymerase Chain Reaction of BBTV}

PCR was conducted to confirm the infection of BBTV from leaf samples. Total viral DNA was isolated from infected leaf following a procedure described by Doyle and Doyle (1987) with minor modification. Fresh tissue (0.1 g) was ground in liquid Nitrogen to powder, $500 \mu \mathrm{l}$ of CTAB buffer $(10 \%$ Cetyl-trimethyl-ammonium bromide, 0.1 $\mathrm{M}$ Tris- $\mathrm{HCl} \mathrm{pH} 8,0.05 \mathrm{M}$ EDTA, 0.5 M $\mathrm{NaCl}, \quad 1 \% \quad \beta$-mercapto-ethanol) was added, and the sap was transferred to 1.5 $\mathrm{ml}$ clean tube. The sap was incubated in water bath at $65 \mathrm{oC}$ for $1 \mathrm{hr}$, then shaked every $10 \mathrm{~min}$ to separate lipid and protein. $500 \mu \mathrm{l}$ of chloroform/ iso-amyl alcohol $(24: 1, \mathrm{v} / \mathrm{v})$ was added to the liquid, then tube was vortexed for $5 \mathrm{~min}$, and centrifuged at $14000 \mathrm{rpm}$ for 15 min. The supernatant was pipetted to 1.5 $\mathrm{ml}$ clean tube, $3 \mathrm{M}$ ammonium acetate and isopropanol of 1/10 and 2/3 volume supernatant, was added respectively. The liquid was mixed gently then incubated overnight at $-20 \mathrm{oC}$ or $4 \mathrm{hr}$ at room temperature. After incubation, the liquid was centrifuged at $12000 \mathrm{rpm}$ for $10 \mathrm{~min}$ to precipitate DNA and then discarded flow-through. The pellets were washed with $500 \mu \mathrm{l}$ of $70 \%$ ethanol, centrifuged at $8000 \mathrm{rpm}$ for $5 \mathrm{~min}$ and dried under room temperature after discarding the flow through. Dried pellets containing total DNA were dissolved in 50 to $100 \mu \mathrm{l}$ of nuclease free water or TE buffer ( $\mathrm{pH} \mathrm{8)}$ ) and the DNA was ready for amplification.

DNA can be used as DNA templates for further PCR amplification using two specific primer pairs for BBTV CP1/FCCCGGGAGAATACTTCACTGG GCTAT GATT and CP1/R CCCGGGCTTCACCTTGCACACCAAC A GCAT with target sequence $1083 \mathrm{bp}$ (Mansoor et.al. 2005). Amplification of DNA was conducted based on method described by Kumar et al. (2011). The DNA was amplified in GeneAmp PCR system 9700 machine with $5 \mathrm{~min}$ at $94{ }^{\circ} \mathrm{C}$ for pre-heating, followed by 35 cycles of denaturation $\left(30 \mathrm{~s}\right.$ at $\left.94{ }^{\circ} \mathrm{C}\right)$, annealing $\left(45 \mathrm{~s}\right.$ at $\left.55^{\circ} \mathrm{C}\right)$, and extension (30s at 72 $\left.{ }^{\circ} \mathrm{C}\right)$, with final extension of $7 \mathrm{~min}$ at 72 ${ }^{\circ} \mathrm{C}$. Amplicons was then visualized on $1 \%$ agarose gel using electrophoresis in TBE 0.5x buffer. The PCR was conducted on twelve symptomatic banana samples.

\section{RESULTS AND DISCUSSION}

\section{Symptoms of BBTV}

Symptom of BBTV can be observed on the lamina of the leaves. The initial symptoms were characterized by the appearance of dark green streak and dots on petiole and lower part of lamina, also slightly chlorotic margins along the new developing leaves. However, the dark green streak can be absent from some cultivars and severe symptoms usually developed since the first leaf of plants derived from infected planting materials (Thomas 2008). The general symptoms that observed in all banana crops in Bengkulu involved upturned leaves, chlorotic and ragged margins (figure $1 \mathrm{~A}$ ), with leaves failed to emerge and stunting (figure $1 \mathrm{C}$ ). Generative plant failed to develop fruits (figure 1B) 


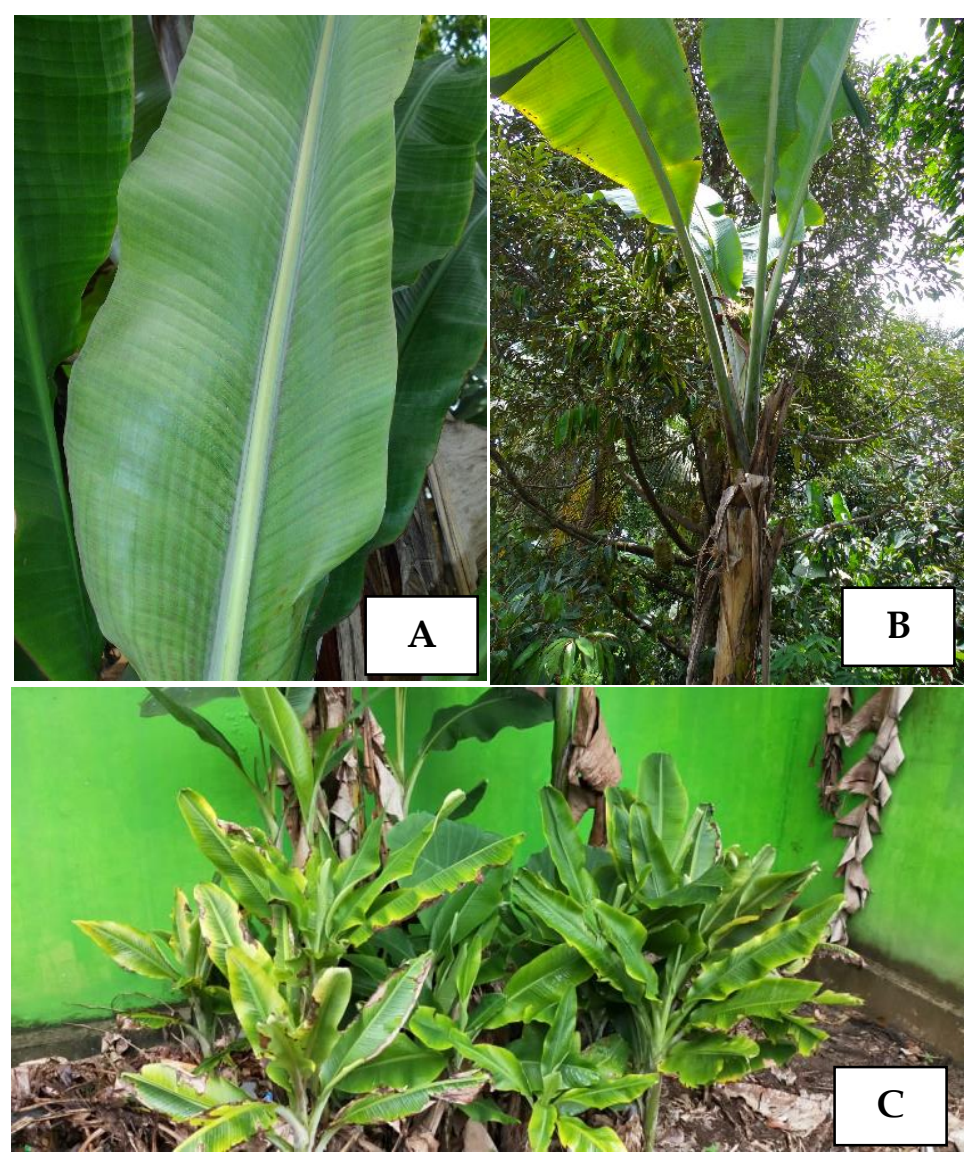

Figure 1. Cultivated banana plants showing mild symptom (A), failed to developed fruits (B), and stunting (C) of BBTV infection in several cultivation area at Bengkulu

The incidence of BBTD in banana plantation in Bengkulu ranged from $0 \%$ to $100 \%$ (table 2). The highest disease incidence was observed on 'Mas' varieties in Singaran Pati (Bengkulu city) and 'Jantan' varieties in Dusun Curup (Bengkulu Utara) with DI value of $100 \%$, while the lower DI were observed on 'Kepok' varieties in Bengkulu city. The most common symptoms observed in the field involved vein clearing, upturned leaf, chlorotic, and ragged margins with reduction in petiole length, distance, lamina width, and stunting. Banana crops that infected with BBTV in the vegetative phase will not produce fruit, while viral infection in the generative phase causes the formation of stunted fruit that is not suitable for harvesting. Thus, the potential loss of yield due to stunted disease can reach $100 \%$.

A study of BBTV epidemiology in Burundi, Africa indicated that incidence of BBTD significantly varied according to trial location, banana cultivar and planting materials (Niyongere et al. 2011). Based on this study, 'Mas' and 'Jantan' varieties is susceptible to BBTV infection, while no disease symptom on 'Kepok' vareties. Previous research in Indonesia reported that 17 out of 38 banana cultivars that grown in banana germplasm field in Yogyakarta were infected by BBTV, with 5 cultivars ('Kepok Gabu', 'Raja Entos', 'Raja Trunpong', 'Rejang' and 'Tanduk Hijau') among them were positively infected without virus symptoms (Furuya et al. 2004). There are no comprehensive report confirming any banana cultivars that 
Table 2. Disease incidence and disease severity of BBTD in banana crops in Bengkulu

\begin{tabular}{|c|c|c|c|c|}
\hline No & Survey location & Varieties & $\begin{array}{c}\text { Disease } \\
\text { incidence (\%) }\end{array}$ & Disease severity \\
\hline 1 & $\begin{array}{l}\text { Muara Bangkahulu } \\
\text { (Bengkulu city) }\end{array}$ & Mas & $4 / 24(16.67)$ & 4 severe \\
\hline 2 & $\begin{array}{l}\text { Muara Bangkahulu } \\
\text { (Bengkulu city) }\end{array}$ & Kepok & $0 / 36(0)$ & No symptom \\
\hline 3 & $\begin{array}{l}\text { Muara Bangkahulu } \\
\text { (Bengkulu city) }\end{array}$ & Jantan & $12 / 39(30.77)$ & $\begin{array}{c}10 \text { severe } \\
2 \text { intermediate }\end{array}$ \\
\hline 4 & $\begin{array}{l}\text { Sungai serut } \\
\text { (Bengkulu city) }\end{array}$ & Mas & $5 / 19(26.31)$ & 5 intermediate \\
\hline 5 & $\begin{array}{l}\text { Singaran Pati } \\
\text { (Bengkulu city) }\end{array}$ & Mas & $12 / 12(100)$ & $\begin{array}{c}10 \text { severe } \\
2 \text { intermediate }\end{array}$ \\
\hline 6 & $\begin{array}{l}\text { Ratu Samban } \\
\text { (Bengkulu city) }\end{array}$ & Jantan & $10 / 83(12.05)$ & 10 severe \\
\hline 7 & $\begin{array}{l}\text { Teluk Segara } \\
\text { (Bengkulu city) }\end{array}$ & Jantan & $5 / 23(21.74)$ & 5 intermediate \\
\hline 8 & $\begin{array}{l}\text { Dusun Curup } \\
\text { (Bengkulu Utara) }\end{array}$ & Jantan & $20 / 20(100)$ & 20 severe \\
\hline 9 & $\begin{array}{l}\text { Curup Utara (Rejang } \\
\text { Lebong) }\end{array}$ & Mas & $15 / 17(88.23)$ & 15 severe \\
\hline
\end{tabular}

completely resistant to BBTV infection. However, previous study have provided evidence that banana cultivars showed different response against infection of BBTV(Hooks 2008; Niyongere 2011).

Virus Detection using Polimerase Chain Reaction

BBTV was not successfully detected by PCR using specific primer. Futher optimation of PCR reaction using this primer should be conducted for the next study.

\section{CONCLUSION}

Incidence of BBTD in Bengkulu is considered high based on symptom observation. Disease incidence of BBTV in Bengkulu City, Bengkulu Utara and Rejang Lebong ranged from $0 \%$ to $100 \%$. The most common symptoms observed in the field involved vein clearing, upturned leaf, chlorotic, and ragged margins with reduction in petiole length, distance, lamina width, and stunting. BBTV was not successfully detected by RT-PCR using specific primer. Futher optimation of PCR reaction using this primer should be conducted for the next study.

\section{SUGGESTION}

Further research on epidemiology and evaluation of the resistance of banana varieties against BBTV infection should be conducted in order to provide suitable controling methods and virus free planting materials for integrated disease management of banana bunchy top disease.

\section{REFERENCES}

Chiaki Y, Nasir N, Herwina $H$, Jumjunidang, Sonoda A, Fukutomo T, Nakamura M, Iwai H. 2015. Genetic structure and diversity of the Banana bunchy top virus population on Sumatra Island, Indonesia. Eur J Plant Pathol 143 (1): 113-122. doi: 10.1007/s10658-015-0669-9. 
Furuya N, Somowiyarjo S, Natsuaki KT. 2004. Virus Detection from Local Banana Cultivars and the First Molecular Characterization of Banana bunchy top virus in Indonesia. J Agri Sci 49 (3): 75-81.

Hooks CRR, Wright MG, Kabasawa DS, Manandhar R, Almeida RPP. 2008. Effect of Banana bunchy top virus infection on morphology and growth characteristics of banana. Ann of Appl Biol 153: 1-9. doi:10.1111/j.17447348.2008.00233.x.

King $A M Q$, Lefkowitz E, Adams MJ, Carstens EB et al. 2011. Virus Taxonomy: Ninth Report of the International Committee on Taxonomy of Viruses. Burlington (UK): Elsevier Science.

Kumar PL, Hanna R, Alabi OJ, Soko MM, Oben TT, Vangu GHP, Naidu RA. 2011. Banana bunchy top virus in sub-Saharan Africa: investigation on virus distribution and diversity. Virus Res 159 (2):
171-182.

virusres.2011.04.021

Mansoor S, Qazi J, Amin I, Khatri A, Khan IA, Raza S, Zafar Y, Bridon RW. 2005. A PCR-based method with internal control for the detection of Banana bunchy top virus in banana. Mol Biotech 30 : 127-129

Niyongere C, Losenge T, Ateka EM, Nkezabahizi D, Blomme G, Lepoint P. 2011. Occurrence and distribution of Banana bunchy top disease in the Great Lakes Region of Africa. Tree Forestry Sci Biotech 6 (1):102-107.

Pinili MS, Nyana DN, Suastika G, Natsuaki KT. 2011. Molecular analysis of Banana bunchy top virus first isolated in Bali, Indonesia. $J$ Agri Sci 56 (2): 125-134.

Thomas J E. Banana Bunchy Top Virus. 2008. Encyclopedia of Virology. (B.W.J. Mahy and M.H.V. Van Regenmortel, Editors). Oxford (UK): Elsevier. 